hairs and a higher proportion of isolates from trichomycosis were found to belong to Evans' group D.

We are indebted to Dr R. H. Seville, Consultant Dermatologist in Lancaster, and to Dr R. C. Cunningham and his staff at the Royal Albert Hospital in Lancaster for assistance and for permission to examine the patients under their care. We are equally indebted to Dr H. E. Robson and the staff and students of the College of Education, Loughborough, for providing facilities essential for these studies. One of us (D. A. S.) was supported by a grant from the Medical Research Council.

\title{
REFERENCES
}

Crissey, J. T., Rebell, G. C., AND 1952. J. Invest. Derm., 19, 187.

LASKaS, J. J.

Evans, N. M. . . . . . . . . . 1968. Br. J. Derm., 80, 81.

HURLEY, H. J., AND SHELlEy, W. B. . . 1960. The human apocrine sweat gland in

Lane, J. E. . . . . . . . . . . . . 1919. J. Cutan. Dis., 37, 387.

health and disease, Springfield, Illinois.

McBride, M. E., Freeman, R. G., and 1968. Br.J. Derm., 80, 509.

KNOX, J. M.

Mandel, A. D., Wright, K., AND 1964. J. Bact., 88, 1524.

MCKInNON, J. M.

Paxton, F. V. . . . . . . . . . . 1869. J. Cutan. Med., Lond., 3, 133.

Sarkany, I., Taplin, D., and Blank, H. 1961. J. Invest. Derm., 37, 283.

Shehadeh, N. H., AND Kligman, A. M. 1963. Ibid., 40, 61.

\section{BIOCHEMICAL REACTIONS OF DIFFERENT SEROTYPES OF PASTEURELLA HAEMOLYTICA}

\author{
B. J. Shreeve*, I. N. Ivanov $\dagger$ ANd D. A. Thompson \\ Moredun Research Institute, Gilmerton, Edinburgh
}

AcCording to Smith $(1959,1961)$ strains of Pasteurella haemolytica can be divided into two biotypes, A and T, differing in colonial appearance, growth rate, pathogenicity, sensitivity to antibiotics, and biochemical reactions. More recently, Biberstein, Gills and Knight (1960), using an indirect haemagglutination technique based on soluble surface antigens, detected ten serotypes of $P$. haemolytica. This number has now been increased to 12 (Biberstein and Gills, 1962; Biberstein and Thompson, 1966).

Biberstein and Gills found that strains of the 11 serotypes of $P$. haemolytica known at that time could be correlated with the A and T types described by Smith. Serotypes 3, 4 and 10 were type $T$ and the rest were type A. Since, however, they tested fermentation reactions with only a limited range of substrates, and since they examined only one strain each of serotypes 4 and 11 , two strains of serotype 10 and none of serotype 12, it was thought important to test the reactions of several strains representing each of the 12 serotypes with a wide range of substrates. The present paper reports observations made on at least three strains of each of the 12 serotypes of $P$. haemolytica except serotype 8, of which only two strains were available.

Received 24 Sept. 1969; accepted 26 Nov. 1969.

* Present addresses: Veterinary Investigation Centre, Merrythought, Calthwaite, Penrith, Cumberland, and $\uparrow$ Veterinary Institute of Infectious and Parasitic Diseases, Pencho Slaveikov no. 15A, Sofia, Bulgaria. 


\section{MATERIALS AND METHODS}

Organisms. All strains were obtained from outbreaks of lamb septicaemia (Stamp, Watt and Thomlinson, 1955) or sheep pneumonia in England, Scotland and Wales. Five strains, representing serotypes 1, 5, 6 and 12, were isolated in Bulgaria.

Culture methods. Strains were cultured overnight in infusion broth which was prepared by adding 1 per cent. Oxoid bacteriological peptone and 0.5 per cent. sodium chloride to a watery extract of lean beef. The $p \mathrm{H}$ was adjusted to $7 \cdot 2$.

Biochemical tests. Fermentation tests were carried out in the medium recommended by Bosworth and Lovell (1944); 1 per cent. of fermentable substrate was added to a peptonewater base containing 10 per cent. infusion broth and 7.5 per cent. bromthymol blue $(0.04$ per cent. solution, $\mathrm{BDH})$. Tests were incubated at $37^{\circ} \mathrm{C}$ and observed for 14 days.

\section{TABLE}

Fermentation reactions of strains of biotypes $A$ and $T$ of Pasteurella haemolytica

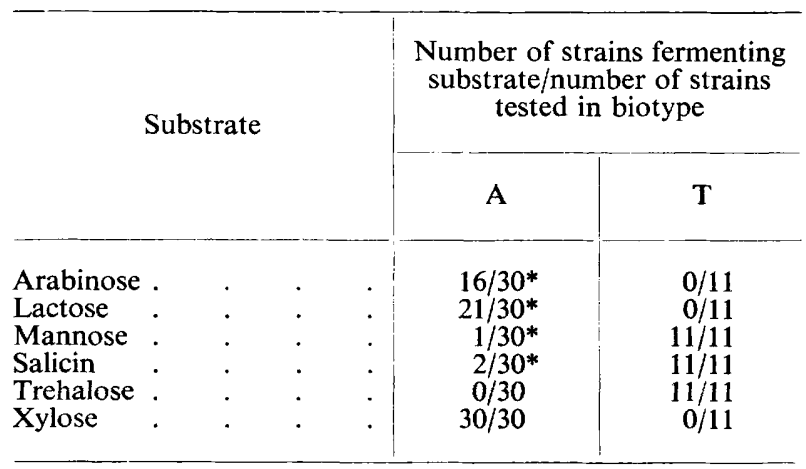

* Exceptional results for strains of biotype A were as follows. Some strains in all serotypes except serotype 11 failed to ferment arabinose. Strains in serotypes 2 and 7 did not ferment lactose. One strain in serotype 11 fermented mannose. One strain in each of serotypes 6 and 11 fermented salicin.

Positive reactions were identified by a colour change from green to yellow. Incomplete colour changes were disregarded. Nitrate reduction, methyl red and Voges-Proskauer tests were included.

\section{RESULTS}

No strain gave acidification in a control medium without fermentable substrate. Adonitol, dulcitol, erythritol, glycerol, inulin and rhamnose were not fermented by any strain. All strains fermented dextrin, fructose, glucose, glycogen, inositol, maltose, mannitol, raffinose, sorbitol, starch and sucrose, and all reduced nitrate and gave negative reactions in the methyl red and Voges-Proskauer tests.

Differences in the fermentation reactions between the $\mathrm{A}$ and $\mathrm{T}$ biotypes tested are shown in the table.

\section{Discussion}

Our findings that adonitol, dulcitol, erythritol, glycerol, inulin and rhamnose were not fermented by any strain of Pasteurella haemolytica agree with those of Smith (1961), except that some of his strains fermented glycerol and rhamnose. Wessman and Hilker (1968) also found no fermentation of adonitol by 42 strains in serotypes 1, 2 and 11. Carter (1967) considered that strains of $P$. haemolytica did not ferment adonitol, inulin or rhamnose, 
but his findings differed from the present results in that most of his strains fermented glycerol and some fermented dulcitol.

The use of arabinose and trehalose to distinguish Smith's (1961) types was shown to be more reliable for the $T$ strains than for the $A$ strains. All $T$ strains fermented trehalose but not arabinose, whereas only a proportion of A strains fermented arabinose although none fermented trehalose.

Smith (1961) also suggested that reactions with glycogen, glycerol, mannose, salicin and starch would provide an indication of the biotype. Our tests with strains representing all 12 serotypes have shown that glycogen and starch were fermented by all strains, glycerol by none, but that reactions with mannose and salicin did indeed given an indication of the different biotypes (see table). According to Biberstein and Gills (1962) both the A and T biotypes fermented mannose, but the fermentation of salicin was confined mainly to $T$ biotypes. We have now found further biotype differences in the reactions with lactose and xylose, neither of which was attacked by $T$ strains. The failure of $T$ strains, and of serotype 2, to ferment lactose was also shown by Biberstein and Gills. In the present work none of the $T$ strains or the strains of serotypes 2 and 7 fermented lactose.

Our finding that all strains gave negative methyl-red and Voges-Proskauer reactions agrees with the observations of Wessman and Hilker.

\section{SUMMARY}

Biochemical tests were made on several strains representing each of the twelve known serotypes of Pasteurella haemolytica. The use of the fermentation reactions with arabinose and trehalose to distinguish the $\mathrm{A}$ and $\mathrm{T}$ biotypes was found to be more reliable for $\mathrm{T}$ than for A strains, since some strains of biotype A in all serotypes, except serotype 11, failed to ferment arabinose within 14 days. Mannose and salicin were fermented by strains of biotype $\mathrm{T}$, but by only 1 (mannose) or 2 (salicin) out of 30 strains in biotype A. Lactose and xylose were fermented by A strains only. All strains reduced nitrate and gave negative reactions in the methyl-red and Voges-Proskauer tests.

We are grateful for the encouragement and advice given by Dr J. T. Stamp and Mr J. G. Brotherston, Director and Deputy Director, respectively, of Moredun Institute, where the work was performed. We are also indebted to Professor E. L. Biberstein for criticism of the manuscript.

\section{REFERENCES}

Biberstein, E. L., ANd Gills, M. G. . 1962. J. Comp. Path. Ther., 72, 316.

Biberstein, E. L., Gills, M., AND 1960. Cornell Vet., 50, 283.

KNIGHT, H.

Biberstein, E. L., And Thompson, D. A. 1966. J. Comp. Path., 76, 83.

BOSWORTh, T. J., AND LOVEll, R. . . 1944. Ibid., 54, 168.

CARTER, G. R. . . . . . . . . 1967. In Veterinary bacteriology and virology,

7th ed., edited by I. A. Merchant and

Sмith, G. R. . . . . . 1959. Nature, Lond., 183, 1132.

R. A. Packer, Ames, pp. 335-353.

," . . . . . . . . 1961. J. Path. Bact., 81, 431.

Stamp, J. T., Watt, J. A. A., AND 1955. J. Comp. Path. Ther., 65, 183.

THOMLINSON, J. R.

Wessman, G. E., and Hilker, G. 1968. Canad. J. Comp. Med., 32, 498. 